\title{
НАУКОВА ХРОНIKA
}

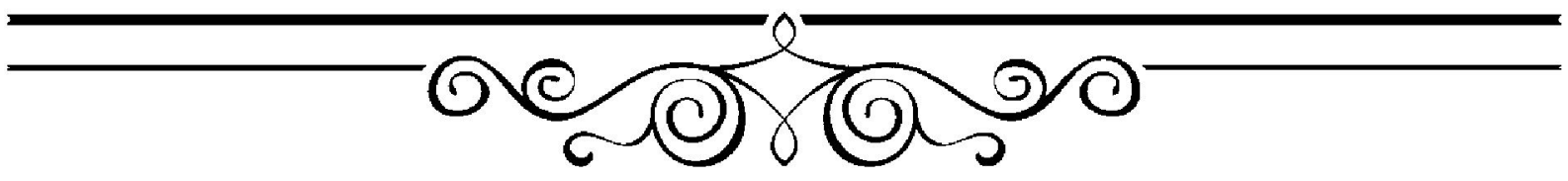

УДК 930 (477) Аліман : [94 : 631.115.8] (477) (045)

DOI: 10.31651/2076-5908-2020-2-128-139

ФАРЕНІЙ Ігор Анатолійович, доктор історичних наук, професор, професор кафедри археології та спеціальних галузей історичної науки Черкаського національного університету ім. Богдана

Хмельницького,

e-mail: fareniy_igor@ukr.net

Orcid ID: 0000-0001-5176-6055

\section{ПОСЛІДОВНИЙ ТРУДІВНИК НА НИВІ ГОСПОДАРСЬКОЇ ПРАКТИКИ, ТЕОРІЇ ТА ІСТОРІЇ УКРАЇНСЬКОЇ КООПЕРАЦІ (3 нагоди 80-річчя Мирослава Васильовича Алімана)}

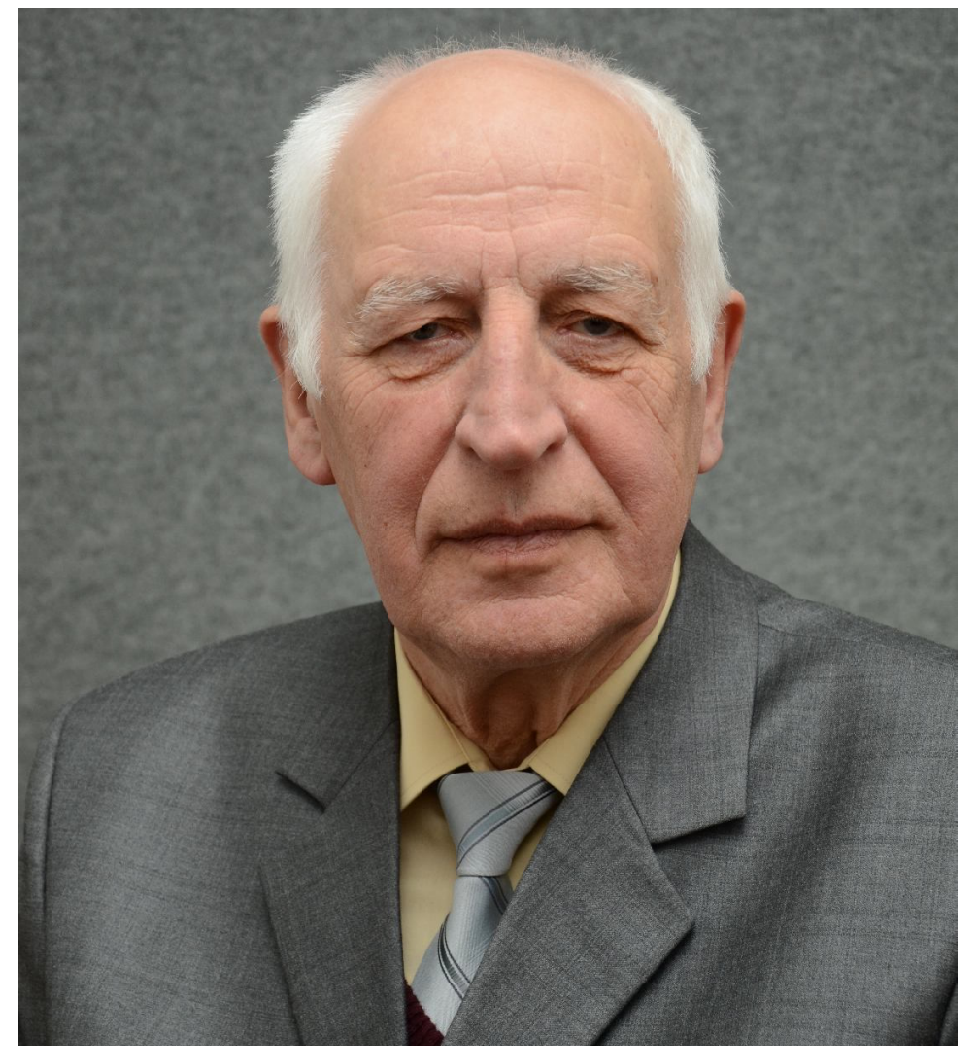

Стаття підготовлена з нагоди 80-річчя з дня народження украӥнського кооператора, вченогоекономіста і історика Мирослава Васильовича Алімана.

М.В.Аліман тривалий час працював у господарських структурах Українськӧ̈ спілки споживчих товариств. Забезпечив вдосконалення роботи споживчої кооперації в Івано-Франківській, Полтавській, Тернопільській, Черкаській, Харківській областях та інших регіонах Украӥни. У 1977 р. захистив кандидатську дисертацію, присвячену проблемам організації кооперативної торгівлі.3 1982 р. М.В.Аліман працює у Полтавському кооперативному інституті університеті економіки і торгівлі. Крім економіко-кооперативних проблем, об'єктом досліджень М.В.Алімана стала історія кооперативного руху. Розробляє проблеми історії культурнопросвітньої роботи кооперації, регіональні аспекти розвитку кооперації, діяльність провідних кооперативних діячів. Ним створена грунтовна праця, присвячена видному представнику суспільної думки XIX cm. і кооператору Миколі Балліну. П'ятитомне видання М.В.Аліман присвятив історії діяльності украӥнського кооперативного і державного діяча Бориса Мартоса. 
Загалом ювіляр є автором понад 400 опублікованих наукових праць.М.В.Аліман ініціатор багатьох громадських проектів. Серед його інічіатив - створення Музею історії Полтавського університету економіки і торгівлі, який він очолює з 2004 p.

Ключові слова: Мирослав Васильович Аліман, кооперативний рух, споживча кооперачія, економіка, історія.

Постановка проблеми та аналіз публікацій. Постать Мирослава Васильовича Алімана вже давно заслужила відображення в літературі [1-7]. Але 80-ріний ювілей створює закономірну нагоду звернутися до аналізу і актуалізації його творчого науковопрактичного набутку. Праця Мирослава Васильовича пов'язана, зокрема, з Черкасами. Тут він займався науково-педагогічною роботою в осередку Полтавського університету економіки і торгівлі, брав участь у всеукраїнських симпозіумах з аграрної історії, інших заходах, публікував свої наукові праці у виданнях Черкаського національного університету імені Богдана Хмельницького. Тому буде справедливим належно присвятити М.В.Аліману сторінки у „Віснику Черкаського університету”.

Мета статті - проаналізувати здобутки організаційно-практичної та наукової роботи Мирослава Васильовича Алімана.

Виклад основного матеріалу. Доля поєднала в постаті Мирослава Васильовича Алімана високий рівень багатогранності праці, їі багатство і послідовність. Він і господарник-практик, і вчений-економіст, і історик, і краєзнавець. При цьому представники усіх категорій громадськості відзначають таку обставину легко із вдячністю. Так, у виданні, присвяченому історії Львівського торговельно-економічно університету, вказується, що діяльність ії випускника фахового економіста Мирослава Васильовича Алімана характеризує його «передусім як історика» $[4,322]$. Однак, не вдаючись у пріоритети праці ювіляра спробуємо розкрити сторінки його організаційно-господарської та науковоорганізаційної, педагогічної, громадської та наукової діяльності.

Життєвий шлях Мирослава Васильовича, до певної міри, схожий на траєкторію життя його ровесників, його покоління. Дитинство припало на роки воєнного лихоліття та повоєнних проблем. Однак, народившись у с. Серафинці Городенківського району на ІваноФранківщині, за сучасними поняттями, «соціальними ліфтами» був покликаний до інтелігентської праці. То були часи, коли дорослішали хутко і становлення відбувалося швидко. Складні і бурхливі перші повоєнні десятиріччя черпали енергію молодих.

17-річним юнаком вступив до Чернівецького кооперативного технікуму. Не без щирого інтересу до кооперації навчався, бо цікавився кооперативними питаннями ще у дитинстві, відвідуючи сільську споживчу крамницю [8]. Між тим, навчання у спеціалізованому навчальному закладі дозволило молодій людині відчути всю сутність справи, до якої долучився. Його біографи відзначають, що у ті роки Мирослав Васильович переконався, що сфера діяльності, до якої він потрапив - це серйозна і солідна, ефективна і визнана у всьому світі система господарювання, а їі основоположники - добре відомі, вшановані і авторитетні люди, чиї справи мають перспективи подальшого втілення $[3,6]$. Мабуть, не без вказаних обставин, з відзнакою закінчивши кооперативний технікум у 1959 р., Аліман продовжив освітнє зростання у Львівському торговельно-економічному інституті.

Навчаючись на четвертому курсі інституту, Мирослав Васильович проходив стажування в універсальній міжрайонній торговельній базі Полтавської облспоживспілки. Так, доля обрала для М.В.Алімана місце розгортання його праці. Полтава - за оцінкою відомого українського державного і кооперативного діяча Бориса Мартоса, «серце України» $[9,226]$ - одержало послідовного трудівника на полі кооперації і науки. Робота студента-стажиста була позитивно оцінена і після закінчення у 1964 році інституту Мирослав Васильович був запрошений на це підприємство. Працювати спочатку почав начальником промтоварного відділу та старшим товарознавцем, але вже 31966 р.- заступником директора бази [5].

Випускник кооперативного вишу разом з практичною організаційно-господарською кооперативної роботою, опановував наукову і педагогічну працю. Майже одразу після завершення навчання в інституті він розпочав науково-педагогічну діяльність. Починаючи 
3 1965-го упродовж трьох навчальних років за сумісництвом працював у Полтавському навчально-консультативному пункті Львівського торговельно-економічного інституту. Викладав основи теорії та історію споживчої кооперації, а також організацію і техніку кооперативної торгівлі.

У 1972 р. М.В. Аліман очолив Полтавський міжобласний Центр наукової організації праці Центрального інституту наукової організації праці, управління і раціоналізації Центроспілки СРСР. Впродовж десятиліття під керівництвом М.В.Алімана на госпрозрахункових засадах проводилися заходи щодо раціоналізації діяльності сотень підприємств торгівлі і громадського харчування, оптових баз, розроблено плани розвитку споживчої кооперації в Полтавській і Харківській областях, опубліковано матеріали про досвід роботи споживчої кооперації Івано-Франківської, Полтавської, Тернопільської, Черкаської областей та інших регіонів [5; 10].

На цьому фоні Мирослав Васильович і в силу своїх безпосередніх обов'язків, а також, очевидно, власної пізнавальної натури активно взявся за науково-дослідну працю. У 1970 р. поступив на заочну форму навчання до аспірантури Львівського торговельноекономічного інституту. Закономірно, що наукова робота М.В.Алімана набула практичного спрямування, була тісно пов'язана $з$ досвідом його організаційно-управлінської діяльності у сфері кооперативної торгівлі. У 1977 р. Мирослав Васильович захистив дисертацію на здобуття ступеня кандидата економічних наук «Вдосконалення торговельної діяльності міжрайонних оптових баз споживчої кооперації» [див.: 11]. Дисертація представила передовий на той час досвід торговельної роботи та методи поліпшення організації діяльності працівників споживкооперації, якості обслуговування споживачів, оптимізації фінансових витрат на доставку товарів та їх поліпшення. Варто зазначити, що у процесі підготовки дисертаційної праці Мирославом Васильовичем були задіяні досвід і матеріали усіх обласних спілок споживчих товариств України та інших організацій споживкооперації республік СРСР. Активно використовував дисертант і дані про практику роботи Черкаської обласної спілки споживчих товариств. Безпосередньо на захисті дисертації Мирославом Васильовичем була відзначена ефективна, у порівнянні з іншими осередками споживкооперації, організація діяльності Черкаської облспоживспілки [10].

Результати дисертаційного дослідження М.В.Алімана мали реальне втілення в практику організаційно-господарської роботи споживчої кооперації. Розроблені у ній методи вдосконалення інфраструктури споживкооперації та організації праці застосовувалися в осередках Української спілки споживчих товариств. При цьому в Полтавській, Сумській та Харківській облспоживспілці Мирослав Васильович брав особисту участь у їх впровадженні [12].

Успішна робота в господарських структурах кооперації, викладацька та наукова діяльність демонстрували багатогранність особистості Мирослава Васильовича та цікаві, поступальні якісні і позитивні зміни на його життєвому шляху. Життя, як кажуть, було на злеті. Здобуття наукового ступеня внесло контрастні корективи у долю Мирослава Васильовича. 31982 р. його постійним місцем роботи став Полтавський кооперативний інститут (нині - Полтавський університет економіки і торгівлі). Розгорнулася, так чи інакше, нова стезя реалізації творчої енергії, багата на сміливі проекти та здобутки.

Перехід у науково-педагогічну сферу не можна не визнати органічним. I це не від того, що Мирослав Васильович задовго до 1982 р. займався науковою та викладацькою діяльністю. Обізнані з характером кооперативної діяльності знають, що справжній кооператор сполучає у собі як здатність до організаційно-управлінської роботи, так і науково-просвітньої. Звичайно, можуть бути і пріоритети. Організаційно-господарська сфера кооперації, очевидно, втратила в особі М. В. Алімана зразково підготовленого у теоретичному і управлінському відношенні керівника-господарника. У науковопедагогічній сфері ресурс Мирослава Васильовича як керівника реалізований був досить помірно - фактично, лише до 1991 р. Однак, науково-педагогічна робота на тривалий час здобула послідовного трудівника на ниві теорії та історії кооперативного руху. Останнє, до речі, не могло порвати зв'язки з господарським простором практичної кооперативної діяльності. Мирослав Васильович з переходом на роботу до Полтавського кооперативного 
інституту і далі присвячував свої наукові дослідження питанням економіки та організаційно-господарській діяльності кооперації, і брав участь в усіх найважливіших подіях кооперативного життя країни. У зв'язку з цим скоріше об'єктивним треба визнати й заняття теорією та історією кооперації. Фах вченого-економіста, очевидно, закономірно зумовлював інтерес до господарських аспектів кооперації на всьому шляху ії розвитку. У свій час всесвітньовідомий вчений-економіст О.В.Чаянов говорив, що справжні перспективи економічної науки пов'язані не лише з розробкою існуючих, а й тих соціальноекономічних укладів, що існували в історичному минулому $[13,143]$. На жаль, далеко не усі сучасні економісти з тим погодилися, чого не скажеш про А.В.Алімана. Визнання об'єктивно існуючого обсягу предмету економічної науки - характерна риса його наукової діяльності чи, вірніше, використаної ним методології наукового пізнання.

Водночас яскраве зображення історичних постатей кооперативного руху, культурнопросвітніх аспектів кооперативного життя, яким також присвячував себе Аліман, вказує на багатство і багатогранність його творчої особистості. Сам Мирослав Васильович говорить, що інформаційний простір Полтавщини незаслужено обминав увагою постаті господарників-кооператорів, які заслуговували пошанування. Це і послужило поштовхом до дослідження історії краю та його діячів [2]. 3 тим і уся історія кооперативного руху стала предметом досліджень Мирослава Васильовича. За цим суто людське ставлення до дійсності, ініціативність та бачення громадських проблем, які слід вирішувати незалежно від обсягу офіційно встановлених посадових обов'язків.

Спочатку старший викладач, але вже згодом завідуючий кафедри економіки і організації кооперативної торгівлі та проректор 3 наукової роботи. Опісля працював доцентом на кафедрах історії та кооперативного руху, кооперації, грошового обігу і кредиту, економічної теорії та прикладної економіки. За час роботи забезпечував викладання багатьох дисциплін, і серед них «Історія і теорія кооперації», «Споживча кооперація», «Кредитна кооперація», «Сільськогосподарська кооперація» та інші. Опублікував більше чотирьох сотень наукових i навчальних праць різного формату: монографії, статті, замітки, нариси, навчальні посібники і підручники [5; 7].

Темпоральність науково-педагогічної праці була високою - Мирослав Васильович встигав відреагувати на усі поточні проблеми епохи, у яку йому судилося жити. За крок від початку роботи у Полтавському кооперативному інституті почалася демократизація другої половини 1980-х та курс Української держави на набуття суверенітету, що не могли не додати Мирославу Васильовичу професійних і громадських устремлінь. Водночас стрімкі соціально-економічні зміни рубежу $1980-90$-х років, очевидно, не могли не викликати аналіз нової господарської, а з тим і кооперативної реальності, та дієві заходи щодо налагодження роботи кооперації в умовах глибоких економічних перетрубацій. Моральнопсихологічне піднесення, очевидно, панувало в лавах тодішніх кооператорів у взаємозв'язку 3 курсом держави на всебічний розвиток кооперативних форм господарювання. I зараз Мирослав Васильович називає той період «відродженням кооперації» [10]. М.В.Аліман брав участь у роботі комісій «Укоопспілки» з розробки проектів нормативних актів кооперативного законодавства, зокрема закону «Про споживчу кооперацію» (1992 р.), «Про кооперацію» (2001 р.), зразкових статутів споживчих товариств і союзів, концепції розвитку української споживкооперації та програми захисту її власності [1; 7]. Мирослав Васильович також був учасником ряду з'їдів споживчої кооперації України.

У 1994 р. вийшла праця М.В.Алімана «Споживча кооперація України в умовах економічної кризи і переходу до ринкової економіки (90-ті роки ХХ ст.)» [14], яка була відгуком на складний процес адаптації до нових умов діяльності. Мирослав Васильович високо оцінював потенціал системи споживкооперації, яка зустріла 1990-ті роки багатогалузевою господарською організацією з розвиненою інфраструктурою, потужним кадровим ресурсом, зрештою- недругорядним місцем у зальних економічних потужностях країни. Разом з тим, констатував зміни в організаційно-господарських засадах діяльності, що полягали в позбавленні споживкооперації державної регламентації щодо ії̈ внутрішньої організації та визначення завдань. Аліман вказував на надзвичайну складність цього процесу новацій, пов'язану із недосконалістю законодавства, та як наслідок - 
неможливістю повноцінної реалізації кооперативних принципів діяльності. Водночас він справедливо зауважував, що й належна законодавча база роботи не могла стати гарантом успішного розвитку кооперації. Загальна економічна ситуація диктувала інші тенденції. У 1990-х роках «дестабілізаційні процеси ... набули катастрофічних ознак». М.В.Аліман пов'язує економічну кризу в незалежній Україні ще з процесами в економіці УРСР у 1970-х - 1980-х роках, до чого не можна поставитися беззастережно. Водночас у роботі подано найсуттєвіші характеристики економічної трансформації відповідного періоду. Мирослав Васильович відверто констатував зменшення обсягів діяльності системи споживкооперації, згортання іiі мережі, проблеми фінансових і кредитних ресурсів, управлінські помилки кооперативного апарату, зрештою - падіння ролі споживкооперації у економічному житті держави та спроби перетворення кооперативних осередків у приватнопідприємницькі структури. Разом з тим, вчений розкрив і заходи з нормалізації організаційно-господарської ситуації, створення нових осередків кооперативної роботи та започаткування нових методів і форм діяльності, своєчасних і позитивних зрушень у споживчо-кооперативному русі, висловив своє ставлення до вирішення визначальних проблем кооперативного життя. Загалом робота М.В.Алімана показує загальну динаміку становища споживчо-кооперативної мережі на рубежі 1980-х - 1990-х років у контексті визначальних тенденцій економічного поступу.

На фоні складнощів соціально-економічного прогресу у 1990-х роках Мирослав Васильович звертався до історичного досвіду діяльності кооперативного руху. У результаті, з'явилися його праці, присвячені історії споживчої кооперації на Полтавщині у першій третині XX ст. $[15 ; 16]$. Звернення до досвіду роботи полтавських кооператорів не можна назвати випадковим чи єдино можливим варіантом здійснення наукової роботи. Полтавська кооперація першої третини XX ст. - була передовим осередком кооперативної роботи в країні і прикладом для наслідування. До аналізу кращих зразків діяльності і звернувся Мирослав Васильович. У роботах Алімана $з$ цієї тематики проаналізовані причини започаткування споживчо-кооперативної роботи на Полтавщині, організаційногосподарський стан кооперативної мережі, політичні, адміністративно-правові та соціально-економічні умови іï діяльності, утвердження кооперації на ринку товарів. Аналізом роботи полтавських кооператорів першої третини XX ст. у вкрай тяжких обставинах, зокрема війни і революції, Мирослав Васильович у черговий раз переконував у велетенських можливостях кооперативного сектора економіки і його спроможність і у сучасну епоху захищати матеріальні інтереси народу. Однак, для цього, як він вказував, «потрібна тільки добра воля влади і лідерів кооперативного руху» $[16,40]$.

В розвитку кооперативного руху Мирослав Васильович високо поставив якості тих, хто претендував на лідерство у ньому. Власне формуванню кадрового ресурсу кооперації він присвятив своє життя, працюючи у Полтавському кооперативному інституті університеті економіки і торгівлі. Одна з випускників згодом характеризувала Мирослава Васильовича як «прекрасну людину, талановитого педагога і фахівця, чудового наставника і організатора» [17]. Однак, не зміг Мирослав Васильович утриматися і від демонстрації широкого спектру образів провідних кооперативних працівників. Його безпосередніми зусиллями (у співавторстві з Ю.М.Гавриленком) підготовлено видання «Видатні діячі кооперативного руху та їх ідеї», яка є своєрідною енциклопедією провідних працівників кооперативної ниви, а з тим і перевірених суспільною практикою якостей, потрібних для кооперативної роботи. Найсуттєвіші здобутки понад ста кооператорів України і зарубіжжя знайшли у цій праці належне вшанування і зафіксування [18]. Причетний Мирослав Васильович й до іншого видання про діячів української кооперації - тритомника «Українські кооператори». Більше десятка відомих постатей кооперативного руху удостоїлися перу Мирослава Васильовича Алімана [див.: 19].

Видному мислителю XIX ст., ідеологу кооперативного руху Миколі Петровичу Балліну М.В.Аліман (у співавторстві з Ю.М.Гавриленком) присвятив спеціальну монографію [20]. Постать Балліна не часто удостоювалася широких наукових дослідів. Сучасна епоха, дякуючи Мирославу Васильовичу, подарувала громадськості докладну працю про «піонера» української кооперації. Ця монографія виконана за усіма канонами науково-дослідної 
роботи, і відзначається докладною історіографічною базою та джерельним забезпеченням. У ній в авторській інтерпретації відображено найсуттєвіші етапи життя і риси кооперативної роботи Миколи Балліна: його творчі зацікавлення і теоретичні погляди на кооперацію, практична організаційна діяльність у сфері кооперативного руху, літературновидавнича праця діяча. Немаловажливо й те, що у книзі показано культурне середовище, з яким взаємодіяв і співпрацював Баллін - тобто, люди, які виконували суспільну місію будівництва кооперативного життя і відзначалися, як пише Аліман, «своїм захопленням і ентузіазмом» $[20,78]$.

Враховуючи роль Миколи Петровича Балліна в розвитку суспільної думки, значення його прикладу кооперативної роботи та характер доступності наукового видання для суспільства, Мирослав Васильович підготував і розраховану на широкий читацький загал сучасних кооперативних працівників серію статей про «піонера» української кооперації [зокрема: 21-22]. А загалом багато десятків газетних статей у кооперативній періодиці опублікував про видатних діячів кооперативного руху, зокрема Шарля Фур'є, Роберта Оуена, Григорія Галагана, Бориса Мартоса, Миколу Верещагіна, Василя Доманицького, Олександра Чаянова та багатьох інших, чим уніс неоцінений внесок у популяризацію кооперативної ідеї та іiі провідників серед широких кіл громадськості.

Серед об’ємистих напрацювань Мирослава Васильовича - виконана разом 3 О.О.Нестулею багатотомна праця, присвячена українському політичному, державному i кооперативному діячу Борису Миколайовичу Мартосу. Серія книжок про Мартоса довголітній фундаментальний проект ювіляра та ректора Полтавського університету економіки і торгівлі О.О. Нестулі. Ще у 1990-х роках Мирослав Васильович приступив до дослідження життя й діяльності Бориса Мартоса. Однак, знадобилося багато років цілеспрямованої праці, щоб увінчати ії публікацією монументальної багатотомної роботи. Власне, у наукову розробку постаті Мартоса влитий весь досвід і сумлінність науководослідної діяльності Мирослава Васильовича та Олексія Олексійовича Нестулі, і що не менш важливо - громадська ініціативність особисто Алімана. Адже останні роки Мирослав Васильович не має стосунку до офіційного працевлаштування. Продуманий план втілення, грунтовна якісна робота 3 джерелами, консультації з зацікавленими фахівцями, громадський супровід проекту із презентаціями, круглими столами у різних інституціях та відзначенням ювілею Матроса на малій батьківщині у Градизьку - все це було сплановано і наполегливо якнайкраще організовано авторами.

На сьогодні вийшло друком п’ять томів праці «Борис Мартос і кооперація», і робота над проектом триває далі. Структура видання має оригінальну постановку - кожен з томів органічно пов'язаний з іншими, але водночас становить самостійну за тематикою книгу. Перша 3 них - власне, узагальнююча монографія про життя й діяльність Б.М.Мартоса [23]. У ній докладно розкрито наполегливу працю діяча українського національного і кооперативного руху у сфері кооперації, політики, науки і освіти. Однак, не лише в змістовності ії цінність і концептуальна вага. Основна ідея книжки - працювати на благо Батьківщини слід за кожних обставин. Як це і робив Борис Мартос - і у дореволюційних умовах, і в революційній борні, і у пореволюційній еміграції. При цьому діяльність Мартоса показано на фоні ключових тенденцій і проблем епохи, у яку він жив.

Кожен з наступних томів відображає внесок Мартоса упевну галузь народногосподарського життя і науки. Друга книга містить докладний аналітичний огляд праць діяча з історії, теорії та практики кооперації, зроблений М.В.Аліманом і О.О.Нестулею, та роботи Мартоса відповідної проблематики, ряд з яких опубліковані вперше [24]. Наступна книга цієї серії «Організація й модерація зібрань у праці Бориса Мартоса» була підготовлена М.В.Аліманом, О.О.Нестулею та С.І.Нестулею і присвячена узагальненню організаційного досвіду Бориса Мартоса. Праця містить розгорнутий аналіз становлення Мартоса як кооперативного діяча, його організаційній роботі у сфері українського кооперативного руху та науково-освітнього життя, а також текст роботи «Організація і ведення зібрань». Остання узагальнила набутий широкою практикою кооперативної роботи та власний досвід Б.М.Мартоса у проведенні громадських заходів, і як стверджують автори і упорядники праці, «не втратила свого значення й тепер» [25, 49 та ін.]. 
Окрема книга присвячена такій немаловажливій проблемі господарської діяльності як ревізія. До ії структури ввійшли докладний «Життєпис Бориса Мартоса» та праця діяча «Кооперативна ревізія» [26].

Не могла бути обділеною увагою й інша праця Мартоса «Теорія кооперації». Об’ємних праць 3 теорії кооперації науці і кооперативному руху подаровано взагалі небагато. Тому публікація цієї достатньо докладної роботи з чималої частки основних питань кооперативного життя має і пізнавальне, і суто практичне значення для вирішення сучасних проблем економіки. Праця має форму курсу лекцій, що дає можливість познайомитися й 3 кооперативними поглядами Бориса Мартоса, й багатьох інших теоретиків, ідеологів та практиків кооперативної справи. Робота загалом охоплює питання соціальної природи кооперації, економічних причин її виникнення і діяльності, видів кооперативної справи, організаційних принципів та традицій. Як і попередні книги, публікація творчо-наукового спадку діяча супроводжується науковою розвідкою про Б.М.Мартоса. У цій книзі, поряд з висвітленням основних етапів кооперативної роботи та іншої громадської праці, основний акцент зроблено на науково-педагогічну діяльність діяча [27].

Візьмемо сміливість сказати: Аліман, разом з О.О.Нестулею, своєю працею поставили своєрідний пам'ятник Мартосу, архітектуру і смисли якого вже не вдасться нікому перевершити на полі дослідження життя і діяльності цього українського діяча. Як сказано в одному з відгуків на цю працю, вона «з часу свого виходу буде служити основним дороговказом в осягненні видатної постаті вітчизняної історії» $[28,150]$.

Справжній вчений не знає віку. I це неодмінне правило суспільного буття цілком очевидно проявилося у долі Мирослава Васильовича. Ні літній вік, ні відсутність офіційної причетності до науково-освітніх установ не призупинили не лише наукову, а й громадськоорганізаційну роботу. Громадська робота - основа кооперативного руху та й взагалі продуктивного поступу суспільства - ніколи не була обділена Мирославом Васильовичем. Вже тривалий час, поряд з науковою і навчальною, кооперативною діяльністю, Мирослав Васильович провадить роботу музейну. Музейна робота склала значний масив науковогромадської праці Мирослава Васильовича. Створення і діяльність Музею історії Полтавського університету економіки і торгівлі, який зафіксував розвиток навчального закладу, а разом з тим і економічний та кооперативний поступ Полтавщини, інших регіонів країни, загалом завдячує саме йому. Мирослав Васильович з властивою об'єктивністю вказує на багатьох ініціаторів та подвижників музейної справи у Полтавському університеті економіки і торгівлі [29]. Мабуть, воно десь так і було, однак інституціоналізація того музею і вихід на стезю стабільної роботи вочевидь завдячує Аліману, що, до речі, визнається авторитетними документами [30]. Комплектування фондів та створення і наповнення експозиції, представництво в усіх необхідних інстанціях та проведення екскурсій завдячує особисто Мирославу Васильовичу. 32004 року проведено близько тисячі екскурсій, у яких взяло участь понад 20 тис. відвідувачів. Експозиція музею розміщена у 20-ти вітринах, що відображають ті проблеми, про які йшлося. Однак, серед багатьох експонатів уважний відвідувач помітить й портрет Тараса Шевченка - подарунок музею правління Черкаської облспоживспілки.

Багатогранність натури Алімана проявляється не лише у його трудовій діяльності кооператора і історика. Мирослав Васильович добре обізнаний з літературою і архітектурою, театром і музичним мистецтвом. Не дивно, що у якості наукового консультанта допомагав створенню пам'ятних знаків на честь видатних кооператорів: Миколи Балліна, Бориса Мартоса, Михайла Туган-Барановського та інших [7]. Автор цієї статті не може не згадати подорож з Мирославом Васильовичем по Черкасам. Архітектура будівель і пам'ятників, планування міста, репертуар драмтеатру і філармонії, поезія Василя Симоненка - не уникли його пильної уваги і оцінки.

Мирослав Васильович характером доброзичливий і категоричний, діловий i дипломатичний, уважний і вимогливий, цілеспрямований і мудрий, послідовний у своєму ставленні до людей, але при всьому - неодмінно спрямований на результат професійної діяльності. Останнє становить, очевидно, зміст його відносин з людьми, гуртує навколо нього науковців і господарників. Мирослав Васильович ініціатор багатьох наукових і 
науково-практичних проектів, організатор їх втілення. Поряд з ним завжди чимало творчих особистостей, яким він приділяв увагу і піклування. Під час роботи у Центрі наукової організації праці спонукав працівників до науково-дослідної роботи, внаслідок чого його фахівці Віра Чорномаз та Іван Швачко захистили кандидатські дисертації, а Наталія Карпенко - кандидатську і докторську дисертації. Колишні студенти Полтавського філіалу Львівського торговельно-економічного інституту, де працював Мирослав Васильович, брати Ігор і Сергій Ніколенки стали докторами економічних наук. М.В.Аліман підтримував фахове зростання асистента Полтавського університету економіки і торгівлі Антоніни Фастовець, що позитивно вплинуло на підготовку нею кандидатської дисертації. Співпраця 3 проф. Т.В.Оніпко подарувала науковій літературі понад три десятка праць з історії споживчої кооперації та краєзнавства. Чимало науково-організаційних проблем Мирослав Васильович вирішував разом з доц. Михайлом Мовчаном.

I науковими, i суто практичними аспектами у сфері кооперації відзначилася співпраця М.В.Алімана з В.В.Гончаренком і А.О.Пантелеймоненком, які досягли статусу докторів наук, професорів, визнаних теоретиків i, що не менш важливо, практиків кооперативної справи. Зацікавленість кооперацією також єднала з багатьма науковцями Полтавського університету економіки і торгівлі: проф. Петром Балабаном, доктором економічних наук Георгієм Скляром, проф. Сергієм Гладким, кандидатом економічних наук Артемом Пожаром та ін. 3 великим натхненням здійснює Мирослав Васильович спільно 3 професорами Олексієм Нестулею, Світланою Нестулею, Юстиною Веригою дослідження діяльності Бориса Мартоса.

Співпрацею відзначені відносини і з вченими інших установ, зокрема професором Львівського торговельно-економічно університету Степаном Гелеєм, професором Московського кооперативного інституту Анатолієм Макаренком, науковцями Бєлгородського університету споживчої кооперації та Гомельського кооперативного інституту. Чимало кооперативно-просвітніх та наукових справ здійснено 3 практиками кооперативної роботи та істориками В.П.Рекрутом і Ф.І.Ленченком.

Як до удач своє долі ставиться Мирослав Васильович до зустрічі на життєвому шляху Василя Коперсака - директора Чернівецького кооперативного технікуму, Семена Сіденка - ректора Львівського торговельно-економічного інституту, Івана Кириченка - директора Полтавської міжрайонної універсальної оптової бази, Степана Кисляка - директора Українського філіалу Центрального інституту наукової організації праці, управління і раціоналізації, Михайла Діанича, Віктора Дорохіна та Олексія Нестулі - ректорів Полтавського кооперативного інституту - університету економіки і торгівлі, співробітників «Вістей Центральної спілки споживчих товариств України». Мирослав Васильович називає ix «прекрасні фахівці і добрі люди». Вони сприяли становленню М.В.Алімана як кооператора-практика та вченого-економіста і історика. Усім їм Мирослав Васильович вдячний, що трапилися на його життєвому шляху [10].

Висновки. Історик і вчений-економіст, практик кооперативної роботи, педагог та ініціатор громадських проектів - класичні ознаки справжнього кооператора $з$ часів зародження, становлення і розквіту кооперативного руху - притаманні Мирославу Васильовичу. Він з честю продовжив не лише традицію, а й саму суть кооператора як інтелектуала і громадського працівника. Зміг це зробити у складних умовах епохи, яка не сильно сприяла кооперативному поступу.

Науково-творча спадщина М.В.Алімана - це науково-пізнавальний ресурс та методологічна база практичної кооперативної роботи. Підготовка законодавства про кооперацію, планів розвитку кооперативного господарювання, підготовка кадрів для кооперації, наділених якостями, випробуваними реальністю кооперативного буття минулого і сучасності - все це стало результатом праці ювіляра. Діяльність Мирослава Васильовича пройшла крізь декілька епох. На жаль, практика життя не завжди належно враховує позиції і можливості таких як Мирослав Васильович щодо економікокооперативних питань, зрештою як і інтелектуального середовища у цілому. Такі вже ознаки минулої і нашої доби. Однак, власну суспільну місію Мирослав Васильович як вчений і практик господарської роботи успішно виконав. 
За сторінками долі М.В.Алімана любов до Батьківщини. Ніщо інше так не змушувало Мирослава Васильовича до такого широкого спектру праці. Можна гадати над мотивами людських дій, і то буває справа складна і невдячна. Однак, послідовні дослідження успішного фахового господарника і економіста Алімана саме у сфері історії вказують на істинну причину його невтомної праці. На зачатті історичної науки в Україні «малоросійські» історики вказали на причину появи історіописання - за цікавістю до історичного минулого - любов до Батьківщини - «до отчизни своєї», як сказано у передмові до Густинського літопису, створення і збереження якого пов'язано з Полтавщиною [31]. Символічно, що наступні століття не дали перерватися ні традиції, ні істинним мотивам творчої праці, i на Полтавщині XX - XXI ст. з усією яскравістю проявилася в Україні широка організаційногосподарська, наукова і громадська робота Мирослава Васильовича Алімана.

\section{Список використаної літератури}

1. Вітаємо! // Вісті Центральної спілки споживчих товариств України. Діловий випуск. - 2005. №39. - 23 вересня. - С.2.

2. Нагірняк О. Літописець кооперації / О.Нагірняк // Вісті Центральної спілки споживчих товариств України. - 2007. - №27. - 5 липня. - С.11.

3. Нагірняк О. Літописець кооперації / О.Нагірняк // Вісті Центральної спілки споживчих товариств України. Діловий випуск. - 2007. - №27. - 6 липня. - С.1, 6, 7.

4. Гелей С.Д. Львівська комерційна академія. Нарис історії / С.Д.Гелей. - Львів: Вид-во Львів. ком. акад., 2008. - 624 с.

5. Аліман Мирослав Васильович : біобібліографічний покажчик / уклад. О. П. Галицька, О. В. Нестеренко: 2-ге вид. випр. й доповн.. - Полтава : РВВ ПУЕТ, 2013. - 92 с.

6. Аліман Мирослав Васильович : біобібліографічний покажчик / уклад. О. П. Галицька, I. О. Нестеренко: 2-ге вид. випр. й доповн.. - Полтава : РВВ ПУЕТ, 2014. - 118 с.

7. [Пантелеймоненко А.О.] Взірець самовідданого служіння кооперативній ідеї / [А.О.Пантелеймоненко] // Вісті Центральної спілки споживчих товариств України. - 2015. №38. - 17 вересня. - С.13.

8. Аліман М.В. для Федяй Т.П. [Лист]. Машинопис. 16.12.2002. - 3 арк.

9. Мартос Б. Визвольний здвиг України / Б.Мартос. - Нью-Йорк; Париж; Сидней; Торонто, 1989. $-320 \mathrm{c}$.

10. Аліман М.В. [Спогади]. Полтава. 1.09.2020 - 13.09.2020. Рукопис, машинопис. $-3+2+5$ н.с.

11. Алиман М.В. Совершенствование торговой деятельности межрайонных оптовых баз потребительской кооперации: автореф. дис. ... канд. екон. наук: 08.00.05 - экономика, организация управления и планирования народного хозяйства (кооперативная торговля) / М.В.Алиман. - Москва, 1977. - 24 с.

12. Центральный институт научной организации труда, управления и рационализации - ЦИНОТУР $[\mathrm{B}]$ Московский кооперативный институт. Специализированный Совет по присуждению ученой степени кандидата экономических наук. [Письмо]. 27.10.1977. Машинопис. - 1 арк.

13. Чаянов А.В. Крестьянское хазяйство: избранные произведения / А.В.Чаянов. - Москва: Экономика, 1989. - 492 с.

14. Аліман М.В. Споживча кооперація України в умовах економічної кризи і переходу до ринкової економіки (90-ті роки XX ст.): історико-економічний огляд / М.В.Аліман. - Полтава: ПКI, 1994. $-48 \mathrm{c}$.

15. Аліман М.В. Розвиток споживчої кооперації Полтавщини на початку ХХ століття / М.В.Аліман. - Москва: Центроспілка, 1995. - 20 с.

16. Аліман М.В. Споживча кооперації Полтавщини у 20-ті роки ХХ століття / М.В.Аліман. Полтава: РВЦ ПУСКУ, 2006. - 44 с.

17. Відповіді на запитання анкети: Яких викладачів згадуєте з особливою вдячністю? Чому? // Вісті Центральної спілки споживчих товариств України. - 1998. - №39. - 24 вересня. - С.8.

18. Аліман М.В. Видатні діячі кооперативного руху та їх ідеї / М.В.Аліман, Ю.М.Гавриленко. Донецьк: Проект, 2000. - 295 с.

19. Українські кооператори. Історичні нариси. У 3-х кн. - Книга 1. - Львів: Укоопосвіта, 1999. 456 с.; Кн. 2. - Львів: Вид-во Львівської комерційної академії, 2001. - 338 с.; Кн. 3. - Вид-во Львівської комерційної академії, 2007. - 328 с.

20. Аліман М.В. Кооператор Микола Баллін. Історичний нарис / М.В.Аліман, Ю.М.Гавриленко. - Донецьк: Новый мир, 2002. - 208 с. 
21. Аліман М. В. Микола Баллін - піонер вітчизняної кооперації/ М. В. Аліман // Вісті Центральної спілки споживчих товариств України. - 1999. - 2 вересня. - С. 5.

22. Аліман М. Він гордився званням кооператора: до 180-річчя від дня народження Миколи Петровича Балліна / М. Аліман // Вісті Центральної спілки споживчих товариств України. 2009. - 3 вересня. - С. 2.

23. Нестуля О.О. Борис Мартос і кооперація. Кн.1: Кооперативна діяльність Б.Мартоса / О.О.Нестуля, М.В.Аліман. - Полтава: ПУЕТ, 2017. - 234 с.

24. Нестуля О.О. Борис Мартос і кооперація. Кн.2: Б.Мартос про кооперацію і кооператорів / О.О.Нестуля, М.В.Аліман. - Полтава: ПУЕТ, 2018. - 246 с.

25. Аліман М.В. Організація й модерація зібрань у праці Бориса Мартоса / М.В.Аліман, О.О.Нестуля, С.І.Нестуля - Полтава: ПУЕТ, 2018. - 196 с.

26. Нестуля О.О. Борис Мартос і його праця про ревізію / О.О.Нестуля, М.В.Аліман, Ю.А.Верига. - Полтава: ПУЕТ, 2019. - 228 с.

27. Нестуля О.О., Аліман М.В. Теорія кооперації Бориса Матроса / О.О.Нестуля, М.В.Аліман. Полтава: ПУЕТ, 2019. - 260 с.

28. Терещенко Т.В. [Рецензія]: Нестуля О.О., Аліман М.В. Борис Мартос і кооперація: монографія. У 2-х кн. Кн.1: Кооперативна діяльність Б.Мартоса / О.О.Нестуля, М.В.Аліман; за ред. О.О.Нестулі. - Полтава: ПУЕТ, 2017. - 233 с. / Т.В.Терещенко // Вісник Черкаського університету. Серія: історичні науки. - Черкаси, 2017. - Вип. 4. - С. 143-150.

29. Аліман М.В. Історія в експонатах / М.В.Аліман // Вісті Центральної спілки споживчих товариств України. - 2004. - №34. - 19 серпня. - С.11.

30. Нагородний лист [Представлення М.В.Алімана до нагородження Почесною грамотою Всеукраїнської центральної спілки споживчих товариств та Центрального комітету Профспілки працівників споживчої кооперації України]. - Полтава, Полтавський університет економіки i торгівлі. 18 червня 2019 р. -1 арк.

31. Густинський літопис // Ізборник. Історія України IX - XVIII ст. Першоджерела та інтерпретації [Електронний ресурс]. - Режим доступу: http://litopys.org.ua/old17/old17_08.htm

\section{References}

1. (2005, September 23). Congratulations! Visti Centralnoyi spilky spozhyvchyx tovarystv Ukrayiny. Dilovyj vypusk (Bulletin of the Central Union of Consumer Societies of Ukraine. Business issue), 39, 2. (in Ukr.)

2. Nagirnyak O. (2007, July 5). Chronicler of cooperation. Visti Centralnoyi spilky spozhyvchyx tovarystv Ukrayiny (Bulletin of the Central Union of Consumer Societies of Ukraine), 27, 11. (in Ukr.)

3. Nagirnyak O. (2007, July 6). Chronicler of cooperation. Visti Centralnoyi spilky spozhyvchyx tovarystv Ukrayiny. Dilovyj vypusk (Bulletin of the Central Union of Consumer Societies of Ukraine. Business issue), 27, 1, 6,7. (in Ukr.)

4. Geley S. D. (2008). Lviv Academy of Commerce. Essay on history. Lviv : Lviv Commercial Academy Publishing House. (in Ukr.)

5. Halytska O. P., \& Nesterenko O. V. (Comps.). (2013). Aliman Myroslav Vasyliovych: biobibliographic index. Poltava : Editorial and Publishing Department of PUET. (in Ukr.)

6. Halytska O. P., \& Nesterenko I. O. (Comps.). (2014). Aliman Myroslav Vasyliovych: biobibliographic index. Poltava: Editorial and Publishing Department of PUET. (in Ukr.)

7. [Panteleimonenko A. O.] (2015, September 17). Example of selfless service to the cooperative idea. Visti Centralnoyi spilky spozhyvchyx tovarystv Ukrayiny (Bulletin of the Central Union of Consumer Societies of Ukraine), 38, 13. (in Ukr.)

8. [Aliman M. V.] (2002). Aliman M. V. For Fedya T. P. [Letter]. Typescript. 12/16/2002. (in Ukr.)

9. Martos B. (1989). Liberation movement of Ukraine. New York; Paris ; Sydney ; Toronto. (in Ukr.)

10. Aliman M. V. (2020). [Memoirs]. 09/01/2020-09/13/2020. Poltava. Manuscript, typescript. (in Ukr.)

11. Aliman M. V. (1977). Improvement of trade activity of interdistrict wholesale bases of consumer cooperation (Extended abstract of Candidate's thesise). Moscow. (in Russ.)

12. (1977). Central Institute of Scientific Organization of Labor, Management and RationalizationTSINOTUR [in] Moscow Cooperative Institute. Specialized Council for awarding the degree of Candidate of Economic Sciences. [Writing]. 10/27/1977. Typescript. (in Russ.)

13. Chayanov A. V. (1989). Peasant economy: selected works. Moscow : Economy. (in Russ.)

14. Aliman M. V. (1994). Consumer cooperation of Ukraine in the conditions of economic crisis and transition to market economy (90s of the XX century): historical and economic review. Poltava : Poltava Cooperative Institute. (in Ukr.) 
15. Aliman M. V. (1995). Development of consumer cooperation in Poltava region in the early twentieth century. Moscow : Central Union. (in Ukr.)

16. Aliman M. V. (2006). Consumer cooperation of Poltava region in the 1920s. Poltava : Editorial and Publishing Center PUSKU. (in Ukr.)

17. (1998, September 24). Answers to the questionnaire: Which teachers do you remember with special gratitude? Why? Visti Centralnoyi spilky spozhyvchyx tovarystv Ukrayiny (Bulletin of the Central Union of Consumer Societies of Ukraine), 39, 8. (in Ukr.)

18. Aliman M. V., \& Gavrilenko Y. M. (2000). Outstanding figures of the cooperative movement and their ideas. Donetsk : Project. (in Ukr.)

19. Geley S. D. (Ed.). (1999-2007). Ukrainian cooperators. Historical essays (3 vols). Lviv : Lviv Commercial Academy Publishing House. (in Ukr.)

20. Aliman M. V., \& Gavrilenko Y. M. (2002). Cooperator Mykola Ballin. Historical essay. Donetsk : New World. (in Ukr.)

21. Aliman M. V. (1999, September 2). Mykola Ballin - a pioneer of domestic cooperation. Visti Centralnoyi spilky spozhyvchyx tovarystv Ukrayiny (Bulletin of the Central Union of Consumer Societies of Ukraine), 5. (in Ukr.)

22. Aliman M. (2009, September 3). He was proud of the title of cooperator: to the 180th anniversary of the birth of Nikolai Petrovich Ballin. Visti Centralnoyi spilky spozhyvchyx tovarystv Ukrayiny (Bulletin of the Central Union of Consumer Societies of Ukraine), 2. (in Ukr.)

23. Nestulya O. O., \& Aliman M. V. (2017). Boris Martos and cooperation (Vol. 1). Poltava : Poltava University of Economics and Trade. (in Ukr.)

24. Nestulya O. O., \& Aliman M. V. (2018). Boris Martos and cooperation. (Vol. 2). Poltava : Poltava University of Economics and Trade. (in Ukr.)

25. Aliman M. V., Nestulya O. O., \& Nestulya S. I. (2018). Organization and moderation of meetings in the work of Boris Martos. Poltava : Poltava University of Economics and Trade. (in Ukr.)

26. Nestulya O. O., Aliman M. V., \& Veriga Yu. A. (2019). Boris Martos and his work on revision. Poltava : Poltava University of Economics and Trade. (in Ukr.)

27. Nestulya O. O., \& Aliman M. V. (2019). Boris Martos theory of cooperation. Poltava : Poltava University of Economics and Trade. (in Ukr.)

28. Tereshchenko T. V. (2017). [Review]: Nestulya O. O., Aliman M. V. Boris Martos and cooperation: a monograph. In 2 books. Book 1. - Poltava : Poltava University of Economics and Trade, 2017. 233 p. Visnyk Cherkas 'kogo universytetu. Seriya: istorychni nauky (Bulletin of Cherkasy University. Series: historical sciences), 4, 143-150. (in Ukr.)

29. Aliman M. V. (2004, August 19). History in exhibits. Visti Centralnoyi spilky spozhyvchyx tovarystv Ukrayiny (Bulletin of the Central Union of Consumer Societies of Ukraine), 34, 11. (in Ukr.)

30. (2019, June 18). Award letter [Presentation of M. V. Aliman for awarding the Certificate of Honor of the All-Ukrainian Central Union of Consumer Societies and the Central Committee of the Trade Union of Consumer Cooperatives of Ukraine]. Poltava, Poltava University of Economics and Trade. 2019. (in Ukr.)

31. Gustin's chronicle. Collection. History of Ukraine IX - XVIII centuries. Original sources and interpretations. Retrieved from http://litopys.org.ua/old17/old17_08.htm

FARENIY Igor, Doctor of Sciences (History), Professor, Professor of Department of Archaeology and special spheres of historical science of Bohdan Khmelnytsky National University of Cherkasy, (Cherkasy,Ukraine),

e-mail: fareniy_igor@ukr.net

\section{CONSISTENT WORKER IN THE FIELD OF ECONOMIC PRACTICE, THEORY AND HISTORY OF UKRAINIAN COOPERATION (On the occasion of the 80th anniversary of Myroslav Vasyliovych Aliman)}

\footnotetext{
Abstract. Introduction. In September 2020, the Ukrainian cooperator, scientist-economist and historian Myroslav Vasyliovych Aliman celebrated his 80th birthday. The anniversary gives an occasion to analyze the life path and scientific achievements of the figure.

Purpose of the article - to analyze the achievements of organizational, economic and scientific work of Myroslav Vasyliovych Aliman.

Results. Myroslav Aliman was born in 1940 and grew up in a peasant family. After graduating with a degree in economics, he quickly made a career in the economic structures of the Ukrainian Union of
} 
Consumer Societies. He worked as a warehouse manager, deputy director of the wholesale base of the Poltava Union of Consumer Cooperatives. For ten years he headed the Poltava regional center of scientific organization of labor of cooperative institutions. In this position, Aliman improved the work of consumer cooperation in Ivano-Frankivsk, Poltava, Ternopil, Cherkasy, Kharkiv regions and other regions of Ukraine.

In 1977, M. V. Aliman defended his dissertation for the degree of Candidate of Economic Sciences (Ph.D.), which is devoted to the problems of organization of cooperative trade. Since 1982, Aliman has worked at Poltava University of Economics and Trade as a senior lecturer, associate professor, head of the department, vice-rector and honorary professor of the university. In the transition to a market economy, M. V. Aliman was involved in the development of cooperative legislation of Ukraine, plans for the development of consumer cooperation. In his scientific works he analyzed the state of adaptation of cooperative organizations to new economic conditions.

The history of the cooperative movement also became the object of M. V. Aliman's research. Develops problems of the history of cultural and educational work of the cooperative, regional aspects of the development of the cooperative, the activities of leading cooperative figures. He created a thorough work dedicated to a prominent representative of public opinion in the nineteenth century and cooperator Nikolai Ballin. M. V. Aliman dedicated the five-volume edition to the history of the activity of the Ukrainian cooperative and political figure, the Prime Minister of the Ukrainian People's Republic Borys Martos. In total, Aliman is the author of more than 400 published scientific works.

M. V. Aliman is the initiator of many public projects for the development of cooperation. Among his initiatives is the creation of the Museum of History of Poltava University of Economics and Trade, which he has headed since 2004.

Originality. For the first time a historiographical review of M. V. Aliman's scientific works on history is presented.

Conclusion. M. V. Aliman's scientific heritage is a cognitive resource and methodological basis of practical cooperative work. The experience of organizing cooperative trade and the activities of dozens of cooperative figures is reflected in the scientific works of the figure.

Key words: Myroslav Vasyliovych Aliman, cooperative movement, consumer cooperation, economy, history.

Одержано редакцією 21.10.2020

Прийнято до публікації 6.11.2020

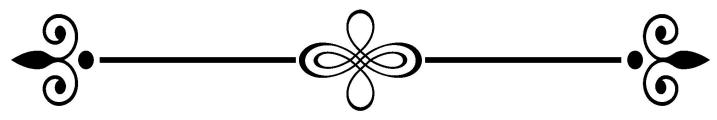

